\title{
Quality of life of patients undergoing specific allergen immunotherapy in allergic rhinitis
}

\author{
Magdalena Brodowicz-Król ${ }^{1, A, C, F \oplus}$, Ewa Guz ${ }^{2, A \oplus}$, Dorota Hawryluk ${ }^{3, A, E \oplus}$, Ewa Kulbaka ${ }^{4, C-D \oplus}$, \\ Lech Panasiuk ${ }^{5, \mathrm{~F} \oplus}$, Piotr Lutomski ${ }^{6, \mathrm{D} \oplus}{ }^{\oplus}$, Paulina Kaczor-Szkodny ${ }^{7, \mathrm{~B} \oplus}$, Piotr Choina ${ }^{6, \mathrm{D} \odot}$ \\ ${ }^{1}$ Medical University, Lublin, Poland \\ ${ }^{2}$ University of Economics and Innovation, Department of Human Science, Lublin, Poland \\ ${ }^{3}$ Center of Allergology, Lublin, Poland \\ ${ }^{4}$ University of Radom, Poland \\ ${ }^{5}$ Institute of Rural Health, Lublin, Poland \\ ${ }^{6}$ Department of Medical Anthropology, Institute of Rural Health, Lublin, Poland \\ ${ }^{7}$ Department of Epidemiology and Biostatistics, Institute of Rural Health, Lublin, Poland \\ $A$ - Research concept and design, B - Collection and/or assembly of data, C - Data analysis and interpretation, \\ $D$ - Writing the article, E-Critical revision of the article, F- Final approval of article
}

Brodowicz-Król M, Guz E, Hawryluk D, Kulbaka E, Panasiuk L, Piotr Lutomski, Paulina Kaczor-Szkodny, Piotr Choina. Quality of life of patients undergoing specific allergen immunotherapy in allergic rhinitis. Ann Agric Environ Med. 2020; 27(4): 657-663. doi: 10.26444/aaem/127840

\begin{abstract}
Introduction. Although allergic diseases have been known since antiquity, both their understanding and systematics came later. The World Allergy Organization (WAO) defines the phenomenon of atopy as a predisposition of a person or family to the uncontrolled synthesis and release of IgE antibodies. Allergic rhinitis (AR) is one of the most important clinical diseases of rhinitis (NN, rhinitis). AR significantly reduces the quality of life, tends to increase, and its consequences may be life-threatening diseases.

Objective. The aim of the study is to determine the quality of life of patients who underwent specific allergen immunotherapy in allergic rhinitis.

Materials and method. The study was conducted at the Center for Specialist Allergology in Lublin between October 2018 - February 2019. The study covered a group of 157 patients. The diagnostic method used was a questionnaire. The first research tool was own questionnaire consisting of 31 questions. The second tool was the standardized questionnaire, the Polish version of the SF-36 Quality of Life Questionnaire.

Results. Studies have shown statistically significant changes in the symptoms of before and after immunotherapy, which means improving the quality of life and reducing the severity of symptoms and problems of respondents after therapy. The respondents were not in the best of health (50\%). Over $50 \%$ of respondents said that the immunotherapy process significantly reduced personal / family expenses for treatment associated with allergic rhinitis.

Conclusions. The conducted process of specific allergen immunotherapy improved the quality of life of respondents by increasing awareness of the quality of life through the prism of health change in relation to the general indicator in the area of mental problems by reducing their nuisance value more than in the area of somatic symptoms.
\end{abstract}

Key words

allergic rhinitis, allergen immunotherapy, nasal functions, quality of life

\section{INTRODUCTION}

Allergic rhinitis (AR), or allergic seasonal rhinitis (SAR), is one of the most important clinical varieties of rhinitis and reduces the quality of life [1]. It is one of the most common diseases affecting adults $[2,3]$ and the most common chronic disease in children [2] (40\%) [3] in the United States [2]. It is estimated that AR affects $20-30 \%$ of adults in both the United States and Europe [4]. The decrease in the quality of life is influenced by, among others, paroxysmal sneezing and itchy nose which become very bothersome in everyday functioning [5]. A serious threat is the progression of disease symptoms, the so-called 'allergic march' that can lead to bronchial asthma. Therapeutic management in patients with allergic rhinitis includes various forms of treatment as well as prevention. One form of therapeutic action is the process of

Address for correspondence: Magdalena Brodowicz-Król, Medical University, Profesora Antoniego Gębali 6, 20-093 Lublin, Poland

E-mail: brmagdalena@gmail.com

Received: 22.04.2020; accepted: 23.09.2020; first published: 29.09.2020 specific immunotherapy which changes the natural course of allergic diseases, prevents the development of new allergies, as well as the development of asthma in patients with AR [1]. Help from medical staff is important - including nurses whose role is to support the patient in the long-term treatment process which is allergen immunotherapy. A particularly important task of the nurse in the case of allergic rhinitis patients is active participation in the immunotherapy process as one form of treatment. Cooperation with the patients and their families, as well as overseeing the correct course of this process, is to make them aware of the life quality of patients with SAR before starting therapy and how it changes during and after the therapy [6]. Available literature on the subject shows that Japan is one of the leading countries in the world for developing recommendations and has been dealing with this since 1993 [7].

Characteristic of specific allergen immunotherapy. Allergen immunotherapy, called specific immunotherapy, has been used for nearly 100 years in the treatment of allergic diseases. 
Modern allergen vaccines are characterized by a high degree of purification and standardization, ensuring effectiveness and increasing safety [8]. Immunotherapy interferes deeply in the basic mechanisms of allergy and allergic inflammation, and its effectiveness goes beyond alleviating the symptoms arising from contact with an allergen [9]. Specific allergen immunotherapy is the only method of causal treatment for allergic rhinitis. A properly selected and used allergen vaccine also gives the chance to stop the progression of atopic allergy and the formation of new allergies [10]. It consists in administering gradually increasing doses of allergen to a patient with IgE-dependent allergen allergy in order to achieve immunological and clinical tolerance [11]. Allergen immunotherapy has a positive effect on the longterm improvement of the symptoms of rhinoconjunctivitis and allergic asthma. Simultaneously, it reduces the need for symptomatic drugs.

There are reports in the literature that show the beneficial effects of alerene immunotherapy before the development of asthma in children with allergic rhinitis [12]. Specific allergen immunotherapy causes many changes at the cellular and humoral level, including a shift of the Th2 immune response towards a Th1 type immune response, which is associated with an increase in regulatory $\mathrm{T}$ lymphocytes and $\mathrm{B}$ lymphocytes, and also a reduction of effector cells and eosinophils in tissue [13]. Effective allergen-specific immunotherapy (AIT) provides the opportunity to restore allergen tolerance and provides treatment that modifies the course of the disease in the long term [14]. Succesful therapy should be long-term and a minimum of three years of therapy is recommended [15].

Allergic inflammation develops in the immune system's response to an allergen [16]. In the initial phase of SIT (specific allergen immunotherapy), a transitory increase in the concentration of allergen-specific $\operatorname{IgE}$ antibodies is observed. Over the course of several months of therapy, it gradually decreases [17]. The reduction of the body's reactivity to the allergen, observed as a result of SIT, cannot be due to its rather weak effect on the concentration of $\operatorname{IgE}$ in the body [10]. IgG4 antibodies produced as a result of SIT significantly modulate the immune response during natural exposure to the allergen and reduce clinical symptoms. Due to the effector mechanisms, a relationship between a lower number of immune cells in the nasal mucosa in the pollen season and a decrease in the severity of clinical symptoms of allergic rhinitis was observed in patients treated with SIT. As a result of the effect on effector mechanisms, effective SIT leads to the reduction in allergic inflammation and, consequently, a reduction in skin reactions, bronchial obstruction, nasal and conjunctival symptoms after both allergen-controlled challenge and natural exposure to the allergen [18]. In patients treated with sublingual specific allergen immunotherapy (SLIT), changes occur at the level of cellular and humoral immune mechanisms similar to those observed in the course of specific allergen immunotherapy administered by subcutaneous injection (SIT) [9].

Areas of problems affecting the quality of life of patients with allergic rhinitis who undergothea process of specific allergen immunotherapy. Patients with allergic rhinitis manifest a large variety of symptoms associated with the above conditions [19]. The AR variety of symptoms can be controlled by avoiding allergens and using pharmacotherapy
[20]. The pharmaceutical management of allergic rhinitis depends on symptomatic treatment with antihistamines [4]. Nevertheless, this form of control is not sufficient for many patients. Constantly persistent symptoms and deterioration in the quality of life, and often the adverse effects of pharmacotherapy, cause allergen immunotherapy (AIT) to be the only treatment currently available that targets underlying pathophysiology and can have diseasemodifying effects [15]. The symptoms presented by patients relate to different areas and spheres of personal and social life, significantly affecting the quality of patients' lives before and after specific allergen immunotherapy [19]. The quality of life is perceived in medicine as a multidimensional phenomenon because it concerns various areas of human functioning, e.g. physical condition and mobility, mental state, social situation and economic conditions, as well as somatic sensations $[20,21]$. The study shows three areas of symptoms and related problems that affect patients with AR:

area of somatic symptoms: nasal blockage, sneezing, watery nasal discharge, itching of the nose, runny secretion down the throat, sore throat, dryness and itching, redness of the eyes, itching of the eyes, watery eyes, swollen eyelids and eye pain, headache.

The area of mental problems: difficulty in concentrating, anxiety and nervousness, irritability and frustration, impact on the quality of life of the family / partner.

The area of physical problems: regularly performed indoorand outdoor activities, other regularly performed activities, sleep disorders, chronic fatigue and exhaustion, rapid fatigue, reduced performance, discomfort caused by the necessity of frequent nose cleaning, frequent rubbing the eyes and nose, great discomfort caused by the need to take medication [22].

Preventive measures can be a key support for improving the quality of life when using allergen immunotherapy. The European Academy of Allergology and Clinical Immunology (EAACI) has developed clinical practice guidelines and recommendations, including prevention of the development of allergic diseases in people with established allergic diseases [23].

\section{OBJECTIVE}

The aim of the study is to determine the quality of life of patients who underwent specific allergen immunotherapy in allergic rhinitis

\section{MATERIALS AND METHOD}

The study used diagnostic survey methods as indirect measurements, and the tools used were two survey questionnaires presented directly to the respondents who answered the questions of the questionnaires in writing. The first tool used was an own questionnairewhich contained information for the respondent regarding the purpose of the survey, which consisted of 31 questions with a metric of eight questions. The second tool was a standardized, Polish version of the SF-36 questionnaire about the quality of life. The research questionnaire was developed for research purposes, although it was not validated. The survey questionnaires were either completed on the spot or 
taken home by the respondents and returned directly to the researcher on subsequent visits after prior consent.

To classify the surveys and selection of respondents, sample surveys were used on the examined 43-person statistical group of the examined population, i.e. patients with allergic rhinitis subjected to the SIT process. Given the contact with the patients surveyed, it was a direct survey. The types of questions used in the questionnaires were open and closed questions, with the possibility of an unambiguous answer, 'yes', 'no' or 'I do not know', as well as questions with a possible set of answers as disjunctive questions, giving the respondent the possibility to select only one version of the answer. The formulation of questions was guided by the selection of an appropriate vocabulary understandable to all respondents, and maintaining a reference point which in this case was the disease presented and the therapy carried out. Due to the fact that the respondents' therapy process lasted between three and five years, some of the questions in the own questionnaire were of a retrospective nature concerning symptoms and behaviour before starting therapy. In contrast, the SF-36 quality of life questionnaire concerned the assessment of respondents after the therapy. By completing the survey questionnaires, respondents marked their answers with an ' $x$ ' in the appropriate boxes, with the exception of the question about occupation which respondents answered in a descriptive form.

Subjects. 160 respondents took part in the study on the quality of life of patients undergoing specific allergen immunotherapy in allergic rhinitis, of whom 157 were included in the study group. Three respondents did not return the questionnaires.

The study was conducted from October 2018 - February 2019 at the Centre of Allergology of Specialist Allergology Clinic in Lublin, eastern Poland. The group of 157 patients aged $18-65$ years were divided into two age groups: $18-49$ years $(69.43 \%)$ and $50-65$ years $(30.57 \%)$. Women constituted $49.68 \%$ of the study group and men $50.32 \%$. The studied group of AR population subjected to SIT was also distinguished by place of residence, education and occupation. Rural patients (30.57\%) and urban patients (69.43\%) were distinguished. Education presented: primary (6.37\%), vocational (15.92\%), secondary (28.03\%) and higher (49.68\%). Due to the wide variety of occupations among the respondents, certain subcategories were formed, taking into account the nature of the profession: mental work performed indoors (40.13\%), mental work performed outside (3.18\%), physical and mental work performed inside premises (21.66\%), physical and mental work performed outside (15.29\%), manual work performed indoors (14.01\%), manual work performed outside (5.73\%).

Statistical analysis. The obtained results were subjected to statistical analysis. The values of the measurable parameters analyzed were presented as the mean, median, minimum and maximum values, lower and upper quartile, and standard deviation, and for non-measurable by means of count and percentage.

Student's t-test was used to investigate the differences between the two independent groups. R-Pearson correlations were also used to check the relationship between some variables. A level of significance of $p<0.05$ indicating the existence of statistically significant differences or dependencies was adopted. The database and statistical research were based on Statistica 9.1 computer software (StatSoft, Poland).

\section{RESULTS}

160 respondents, of whom 157 people were included in the study group, attended the study on the quality of life of patients subjected to specific allergen immunotherapy in allergic rhinitis. Three respondents did not return questionnaires.

Table 1. Characteristics of the researched group

\begin{tabular}{|c|c|c|c|}
\hline \multicolumn{2}{|c|}{ Analyzed variable } & \multirow{2}{*}{$\begin{array}{c}\mathbf{N} \\
78\end{array}$} & \multirow{2}{*}{$\begin{array}{c}\% \\
49.68\end{array}$} \\
\hline & women & & \\
\hline 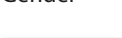 & men & 79 & 50.32 \\
\hline \multirow{2}{*}{ Age } & $18-49$ & 109 & 69.43 \\
\hline & $50-65$ & 48 & 30.57 \\
\hline \multirow{4}{*}{ Education } & primary & 10 & 6.37 \\
\hline & vocational & 25 & 15.92 \\
\hline & secondary & 44 & 28.03 \\
\hline & higher & 78 & 49.68 \\
\hline \multirow{2}{*}{$\begin{array}{l}\text { Place of } \\
\text { residence }\end{array}$} & city & 109 & 69.43 \\
\hline & countryside & 48 & 30.57 \\
\hline \multirow{6}{*}{ Profession } & mental work performed indoors & 63 & 40.13 \\
\hline & mental work performed outside & 5 & 3.18 \\
\hline & manual and mental work performed indoors & 34 & 21.66 \\
\hline & manual and mental work performed outside & 24 & 15.29 \\
\hline & manual work performed indoors & 22 & 14.01 \\
\hline & manual work performed outside & 9 & 5.73 \\
\hline Total & & 157 & 100.00 \\
\hline
\end{tabular}

$82.17 \%$ of patients underwent the conventional method of therapy, i.e. they received the allergen in the form of subcutaneous injections with the following preparations: NovoHelisen Depot, Allergovit, Purethal, Phostal or Pollinex. $17.83 \%$ of patients underwent alternative immunotherapy, i.e. they received the allergen in the sublingual way - in the form of drops or tablets with the following preparations: Staloral 300, Oralair. A significant proportion of patients with AR (over 82\%) underwent treatment using conventional allergen immunotherapy (Fig. 1).

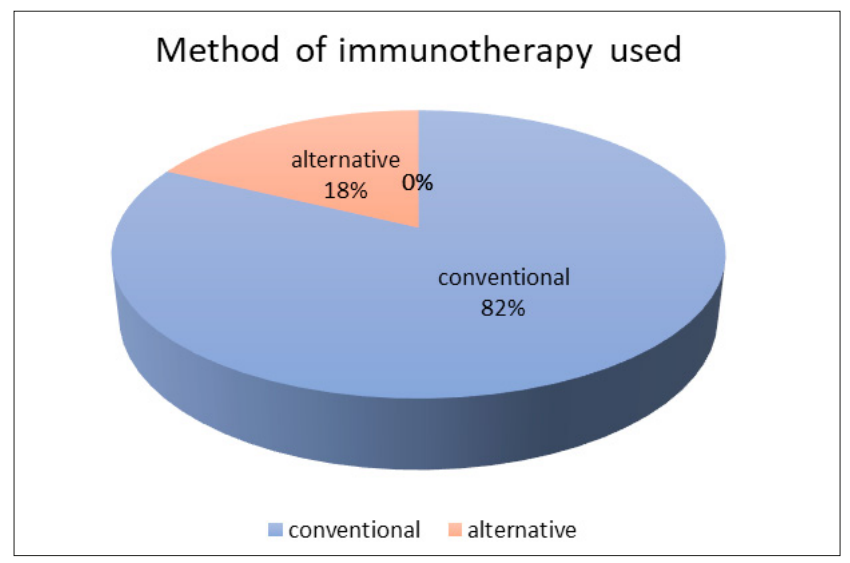

Figure 1. Method of immunotherapy used: conventional (subcutaneous administration of the allergen), alternative (sublingual administration of the allergen - drops, tablets) 
Table 2. Comparison of severity of symptoms before and after immunotherapy

\begin{tabular}{|c|c|c|c|c|c|c|c|c|}
\hline \multirow{2}{*}{ Symptoms } & \multicolumn{3}{|c|}{ Severity of symptoms before immunotherapy } & \multicolumn{3}{|c|}{ Severity of symptoms after immunotherapy } & \multicolumn{2}{|c|}{ Statistical analysis } \\
\hline & M & $\mathrm{Me}$ & SD & M & $\mathrm{Me}$ & SD & $\mathrm{T}$ & $\mathrm{p}$ \\
\hline Area of somatic symptoms & 3.67 & 3.67 & 0.51 & 1.50 & 1.33 & 0.47 & 34.887 & $<0.001$ \\
\hline Area of mental problems & 2.67 & 2.75 & 0.57 & 1.53 & 1.50 & 0.49 & 21.540 & $<0.001$ \\
\hline Area of physical problems & 3.67 & 3.80 & 0.49 & 1.64 & 1.60 & 0.52 & 35.357 & $<0.001$ \\
\hline
\end{tabular}

M - mean; Me - mediane; SD - standard deviation; T - Student's t-test restult for dependent tests; $\mathrm{p}$ - statistical significance.

The results of individual areas are the average of the questions included in the given area, therefore the results are on a scale of 1-5, the higher the score, the more severe the areas of symptoms or problems. For all areas, the value of $p<0.001$ occurred, i.e. there was a statistically significant change in all areas analyzed. Based on the average values, it can be seen that there was a reduction in the severity of symptoms in all areas.

Table 3. Choice of immunotherapy method due to differences in symptoms

\begin{tabular}{|c|c|c|c|c|c|c|c|c|}
\hline \multirow{2}{*}{ Area of symptoms } & \multicolumn{3}{|c|}{ Conventional } & \multicolumn{3}{|c|}{ Alternative } & \multirow{2}{*}{ Z } & \multirow{2}{*}{$p$} \\
\hline & M & $\mathrm{Me}$ & SD & M & $\mathrm{Me}$ & SD & & \\
\hline $\begin{array}{l}\text { Area of somatic } \\
\text { symptoms }\end{array}$ & 3.74 & 3.8 & 0.51 & 3.37 & 3.3 & 0.42 & 3.235 & 0.001 \\
\hline $\begin{array}{l}\text { Area of mental } \\
\text { symptoms }\end{array}$ & 2.72 & 2.8 & 0.57 & 2.46 & 2.5 & 0.54 & 2.013 & 0.044 \\
\hline $\begin{array}{l}\text { Area of physical } \\
\text { symptoms }\end{array}$ & 3.74 & 3.9 & 0.47 & 3.36 & 3.4 & 0.46 & 3.000 & \\
\hline
\end{tabular}

A statistically significant difference was obtained concerning physical problems $(\mathrm{p}<0.001)$ and somatic symptoms $(\mathrm{p}=0.00)$ in patients who were qualified for the conventional method of allergen immunotherapy - they had higher (more severe) symptoms in all domains. The patients with more severe symptoms of AR are referred to the conventional method.

Comparing two age groups, $18-49$ and 50-65, statistically significant differences were noted in the general index of the quality of life ( $\mathrm{p}=0.002)$, and in the quality of life related with physical functioning $(\mathrm{p}<0.001)$, role restrictions caused by emotional problems ( $\mathrm{p}=0.005)$, social functioning $(\mathrm{p}=0.033)$ and pain ( $\mathrm{p}=0.001)$. In all these domains, the patients aged $18-49$ had a better quality of life than those aged $50-65$. This was because that in all these cases the average score in the younger group was higher than the average in the older group.

In the case of education, three groups were compared (I, II, III); therefore, with statistically significant ' $\mathrm{p}$ ' values, information was added which differentiated the groups from one another. Thus, for example, the notation I-III means that

Table 4. Differences in quality of life due to age of respondents

\begin{tabular}{|c|c|c|c|c|c|c|c|c|}
\hline \multirow{2}{*}{ Quality of life } & \multicolumn{3}{|c|}{ aged 18-49 } & \multicolumn{3}{|c|}{ aged 50-65 } & \multirow{2}{*}{ Z } & \multirow{2}{*}{$\mathrm{p}$} \\
\hline & M & $\mathrm{Me}$ & SD & M & $\mathrm{Me}$ & SD & & \\
\hline General index & 73.86 & 77.22 & 11.99 & 69.97 & 72.78 & 9.52 & 3.044 & 0.002 \\
\hline Physical functioning & 87.98 & 90.00 & 12.34 & 81.35 & 85.00 & 12.02 & 3.651 & $<0.001$ \\
\hline Role restrictions due to physical health & 86.47 & 10000 & 27.75 & 84.90 & 100.00 & 24.59 & 0.992 & 0.321 \\
\hline Role restrictions due to emotional problems & 89.91 & 100.00 & 25.05 & 80.56 & 100.00 & 28.21 & 2.804 & 0.005 \\
\hline Emotional well-being & 62.57 & 60.00 & 12.88 & 61.33 & 60.00 & 10.80 & 0.874 & 0.382 \\
\hline Social functioning & 76.26 & 75.00 & 20.05 & 71.88 & 68.75 & 15.58 & 2.133 & 0.033 \\
\hline Pain & 80.48 & 90.00 & 18.96 & 71.67 & 67.50 & 14.66 & 3.266 & 0.001 \\
\hline General health & 50.92 & 50.00 & 10.41 & 49.06 & 50.00 & 11.79 & 1.304 & 0.192 \\
\hline Change of health & 78.67 & 75.00 & 21.74 & 73.44 & 75.00 & 24.95 & 1.138 & 0.200 \\
\hline
\end{tabular}

Table 5. Differences in quality of life due to education of respondents according to the SF-36 quality of life questionnaire

\begin{tabular}{|c|c|c|c|c|c|c|c|c|c|c|c|}
\hline \multirow{2}{*}{ Quality of life } & \multicolumn{3}{|c|}{ I. Primary / vocational } & \multicolumn{3}{|c|}{ II. Secondary } & \multicolumn{3}{|c|}{ III. Higer } & \multirow{2}{*}{$\mathrm{H}$} & \multirow{2}{*}{$\mathrm{p}$} \\
\hline & M & Me & SD & M & $\mathrm{Me}$ & SD & M & Me & SD & & \\
\hline General index & 70.26 & 73.5 & 12.32 & 72.38 & 75.8 & 12.99 & 73.92 & 77.1 & 9.90 & 3.292 & 0.193 \\
\hline Physical functioning & 85.43 & 85.0 & 9.73 & 86.48 & 90.0 & 12.56 & 85.90 & 90.0 & 13.81 & 1.419 & 0.492 \\
\hline Role restrictions due to physical health & 82.86 & 100.0 & 33.08 & 81.82 & 100.0 & 29.71 & 89.74 & 100.0 & 21.10 & 2.426 & 0.297 \\
\hline Role restrictions due to emotional problems & 87.62 & 100.0 & 29.25 & 81.82 & 100.0 & 29.16 & 89.74 & 100.0 & 22.99 & 3.258 & 0.196 \\
\hline Energy / fatigue & 50.14 & 55.0 & 17.88 & 55.57 & 55.0 & 11.06 & 50.00 & 50.0 & 10.06 & 7.840 & $0.020 \mathrm{II-III}$ \\
\hline Emotional well-being & 57.26 & 56.0 & 12.97 & 61.82 & 60.0 & 11.52 & 64.62 & 64.0 & 11.78 & 6.482 & $0.039 \mathrm{I}-\mathrm{III}$ \\
\hline Social functioning & 67.50 & 75.0 & 21.48 & 73.58 & 75.0 & 18.72 & 79.01 & 81.3 & 16.67 & 7.872 & $0.020 \mathrm{IIII}$ \\
\hline Pain & 71.21 & 77.5 & 17.63 & 77.16 & 77.5 & 20.35 & 81.09 & 80.0 & 16.41 & 6.589 & $0.037 \mathrm{IIII}$ \\
\hline General health & 48.29 & 50.0 & 10.98 & 51.93 & 55.0 & 12.68 & 50.38 & 50.0 & 9.59 & 2.804 & 0.246 \\
\hline Change of health & 75.00 & 75.0 & 19.17 & 75.57 & 75.0 & 24.99 & 78.85 & 75.0 & 23.17 & 1.53 & \\
\hline
\end{tabular}


the differences were between respondents with primary / vocational education and respondents with higher education. However, there were no differences between groups I-II and II-III. Statistically significant values were obtained between groups II-III, i.e. perceiving the quality of life by level of energy / fatigue, subjects with secondary education presenteda higher quality of life than subjects with higher education. In the domain of emotional well-being, social functioning and the feeling of pain, a higher quality of life was presented by respondents with higher education than those with basic / vocational education.

Table 6. Relationship between quality of life and symptoms before immunotherapy according to the SF-36 quality of life questionnaire

\begin{tabular}{|c|c|c|c|c|}
\hline \multirow[b]{2}{*}{ Quality of life } & & \multicolumn{3}{|c|}{ Area of symptoms } \\
\hline & & $\begin{array}{l}\text { Somatic } \\
\text { symptoms }\end{array}$ & $\begin{array}{c}\text { Mental } \\
\text { symptoms }\end{array}$ & $\begin{array}{l}\text { Physical } \\
\text { symptoms }\end{array}$ \\
\hline \multirow{2}{*}{ General index } & $\mathrm{r}$ & -0.374 & -0.578 & -0.429 \\
\hline & $\mathrm{p}$ & $<0.001$ & $<0.001$ & $<0.001$ \\
\hline \multirow{2}{*}{ Physical functioning } & $\mathrm{r}$ & -0.184 & -0.341 & -0.217 \\
\hline & $\mathrm{p}$ & 0.021 & $<0.001$ & 0.006 \\
\hline \multirow{2}{*}{ Role restrictions due to physical health } & $\mathrm{r}$ & -0.290 & -0.565 & -0.331 \\
\hline & $\mathrm{p}$ & $<0.001$ & $<0.001$ & $<0.001$ \\
\hline \multirow{2}{*}{$\begin{array}{l}\text { Role restrictions due to emotional } \\
\text { problems }\end{array}$} & $r$ & -0.312 & -0.426 & -0360 \\
\hline & $\mathrm{p}$ & $<0.001$ & $<0.001$ & $<0.001$ \\
\hline \multirow{2}{*}{ Energy / fatigue } & $r$ & 0.005 & -0.190 & -0.083 \\
\hline & $\mathrm{p}$ & 0.952 & 0.017 & 0.302 \\
\hline \multirow{2}{*}{ Emotional well-being } & $r$ & -0.240 & -0.305 & -0.253 \\
\hline & $\mathrm{p}$ & 0.002 & $<0.001$ & 0.001 \\
\hline \multirow{2}{*}{ Social functioning } & $r$ & -0.293 & -0.435 & -0.385 \\
\hline & $\mathrm{p}$ & $<0.001$ & $<0.001$ & $<0.001$ \\
\hline \multirow{2}{*}{ Pain } & $r$ & -0.368 & -0.535 & -0.420 \\
\hline & $\mathrm{p}$ & $<0.001$ & $<0.001$ & $<0.001$ \\
\hline \multirow{2}{*}{ General health } & $r$ & -0.391 & -0.480 & -0.400 \\
\hline & $\mathrm{p}$ & $<0.001$ & $<0.001$ & $<0.001$ \\
\hline \multirow{2}{*}{ Change of health } & $\mathrm{r}$ & -0.638 & -0.444 & -0607 \\
\hline & $p$ & $<0.001$ & $<0.001$ & $<0.001$ \\
\hline
\end{tabular}

The above analysis of the relationship between the quality of life and symptoms before starting the immunotherapy process was based on a coefficient of the r-Pearson correlation. If the correlation coefficient was negative (as occurred in all the above cases), this meant that the higher results of one variable corresponed to the lower results of the other variable. Theref, in the case of the examined group: higher results of the 'area of symptoms' meant higher (worse) symptoms, whereas lower results in the quality of life meant a worse quality of life. It follows that subjects with more intense symptoms before immunotherapy had at the same time a worse quality of life; in other words, more severe symptoms corresponded with a lower quality of life. In addition, attention should be paid to the absolute value of the correlation coefficient, i.e. what is written after the decimal point, without looking at the + or - sign. The higher the value, the stronger the relation between the variables. Thus, for example, there was a stronger relation between the general quality of life index and the 'area of mental symptoms' $(r=-0.578)$ than the general quality of life index with the 'area of somatic symptoms' $(r=-$
0.374). Similarly, there was a stronger relationship between role restrictions based on physical health and quality of life and the 'area of mental symptoms' $(r=-0.565)$ than role restrictions due to physical health and the 'area of somatic symptoms' $(\mathrm{r}=-0.290)$.

\section{DISCUSSION}

The problem of the quality of life of a patient with allergic rhinitis is a problem quite often raised and discussed in the world literature. However, the problem of the quality of life of patients undergoing specific allergen immunotherapy is less frequently discussed.

Due to the large variety of obtained results of research related to AR before and after immunotherapy, comparing their results becomes quite challenging, also when assessing the impact of specific allergen immunotherapy on the quality of life of respondents [24]. With a view to the future, in a multi-centre study by Danish specialists in a group of 248 patients aged over 16 (127 with AR and conjunctiva, 121 with AR and / or conjunctiva and asthma) allergic to grass pollen and / or house dust mites, the impact of annual AIT on the quality of life and QALY was assessed. The quality of life was measured using RQLQ and general scales: 15 areas of quality of life scale $(15 D-15)$ and five areas of quality of life according to the European Quality 5 Dimensions scale (EQ-5D). The result of the study was an increase in the value of the quality of life results in the measurement of each scale, and a significant increase in the QALY index [25]. In the analysis of the own questionnaire and SF-36 quality of life questionnaire regarding the comparison of the severity of symptoms before and after immunotherapy in somatic symptoms, physical and mental problems, an own study obtained a statistically significant change in all the analyzed areas, which means a significant improvement in the quality of life and reduction the severity of symptoms and problems of $\mathrm{AR}$ respondents after the therapy. In a Spanish study, a group of 683 adults with AR was retro-examined and evaluated using three quality of life questionnaires. The effect of AR on occupational activity, daytime activity, HRQoL and satisfaction with the use of allergen immunotherapy were investigated. The conclusions indicated that allergen immunotherapy prevented a decrease in HRQoL (quality of life based on health) and protected against a decrease in productivity at work and in learning [26]. Analysis of the own research showed that there was also a statistically significant change in all analyzed areas regarding the quality of life. Based on the mean values, it was demonstrated that in all areas there was a reduction in the severity of symptoms in patients undergoing specific allergen immunotherapy. In relation to emotional well-being, social functioning and the feeling of pain, a higher quality of life was presented by respondents with higher education than those with basic / vocational education.

As for the conventional method of immunotherapy, there was a significant change in health for the better than in patients who used the alternative method. A study conducted in Poland using the AQLQ and RQLQ questionnaires, in which 200 patients participated (101 with asthma, 99 with allergic rhinitis), after 30-36 months of using immunotherapy, there was a significant improvement in the quality of life in both groups regardless of age and gender [27]. Own research, 
taking into account the age criterion in relation to the quality of life within somatic symptoms, showed that the subjects from the 'younger' and 'older' age groups had similarly intensified symptoms before starting therapy. At the same time, both groups achieved a significant improvement in the quality of life at a similar level. In own research, significant differences in the general quality of life index were noted, i.e. people from the younger age group had a better quality of life related with physical functioning and role restrictions caused by emotional problems and pain. In Polish studies, Rapiejkoet al. showed statistically significant differences related to age, place of residence and occupation, and related to the quality of life of patients with AR in relation to their daily activities. They found that what particularly impeded the performance of these activities were a stuffy nose, the need to wipe the nose, sleep disorders, and disorders limiting physical and mental fitness [28]. The therapy applied to patients with AR significantly reduced the nuisance of performing regular activities and other daily indoor and outdoor activities. The sense of general health, higher quality of life perceived bythe energy / fatigue level was shown more in subjects with secondary education than those with higher education.

The American Agency for Research and Quality of Health Care (AHRQ) has published a report with the results of 142 randomized clinical trials - 74 studies using SCIT, 60 studies using SLIT and eight studies comparing SCIT and SLIT as the way of administering the allergen extract. The conclusions indicatyed a significant improvement in ARdependent quality of life and conjunctiva in patients treated with SCIT, as well as a moderate strength of evidence for an improvement in the quality of life dependent on allergic symptoms in patients treated with SLIT [29]. Own study showed that as much as $68.15 \%$ of the respondents stressed the nuisance and great discomfort of the immunotherapy method and system used. Patients who underwent alternative immunotherapy (SLIT) presented stronger, more severe symptoms after a period of therapy, which significantly influenced their quality of life. The result of the study was an indication that patients with more severe comorbid symptoms associated with AR were referred to the conventional method. In the European systematic review of SCIT and SLIT research with the help of economic analysis and assessment (QALY) funded by the British Institute for Health Research in Health Technology Assessment in Children and Adults with Allergic Rhinitis, both immunotherapy methods have proved more cost-effective than standard pharmacotherapy. The published review found a significant effect of allergen immunotherapy on the cost of treatment of patients with AR with or without asthma [30]. Own study showed that over $50 \%$ of the respondents claimed that the immunotherapy process significantly reduced personal / family expenses on treatment related to allergic rhinitis disease. This is confirmed by the above-mentioned European systematic review of research.

\section{CONCLUSIONS}

1. Due to the applied method and system of immunotherapy, the allergen immunotherapy constituted a great nuisance and discomfort for patients undergoing AR therapy, which slightly reduced the quality of life by increasing physical problems.
2. Respondents subjected to a year-round system of specific allergen immunotherapy showed a difference in reducing the severity of somatic symptoms and physical problems 3. The conducted process of specific allergen immunotherapy improved the quality of life of respondents by increasing awareness of the quality of life through the prism of changing health for the better.

4. The applied alternative method of immunotherapy did not significantly improve the quality of life of the respondents due to a slight reduction in the intensity of somatic symptoms. The subjects who underwent alternative immunotherapy was too small, which is a great limitation to drawing accurate conclusions.

5. Specific allergen immunotherapy significantly improved the quality of life of respondents in relation to the overall index of quality of life for the bette, in the domain of mental problems by reducing their nuisance more than somatic symptoms.

The conducted research shows that patients undergoing alternative immunotherapy presented stronger, more severe symptoms after the therapy, which significantly affected the quality of life. A significant change was achieved in the area of somatic symptoms and physical problems in patients who underwent conventional allergen immunotherapy. These patients were characterized by more severe symptoms in all dimensions before starting therapy. The result of the study was that patients with more severe symptoms with AR were referred to the conventional method. Currently, such a qualification does not apply, the choice of method is dictated rather by the patient's convenience and material possibilities (preparations for alternative therapy are paid 100\%).

Similar relationships were shown in the study with regard to the applied immunotherapy system. Respondents subjected to a year-round immunotherapy system showed a difference in reducing the severity of somatic symptoms as well as physical problems.

\section{Practical implications}

1. Based on the obtained results, it is recommended to repeat the research in a year's time.

2. With regards to the results, it would be advisable to carry out systematic monitoring of facilities where the process of specific allergen immunotherapy is carried out, and monitoring of an alternative method.

3. Efforts should be made to disseminate research results and compare them with other results.

\section{REFERENCES}

1. Rogala B, Glück J. Immunoterapia alergenowa, ed. Kowalski ML, Rogala B. Łódź: MEDITON; 2012.

2. Seidman MD, Gurgel RK, Lin SY, et al. Clinical practice guideline: Allergic rhinitis. Otolaryngol Head Neck Surg. 2015 Feb; 152(1 Suppl): S1-43. doi: 10.1177/0194599814561600

3. Meltzer EO. Allergic Rhinitis: Burden of Illness, Quality of Life, Comorbidities, and Control. Immunol Allergy Clin North Am. 2016; 36(2): 235-248. doi:10.1016/j.iac.2015.12.002

4. Hoyte FCL, Nelson HS. Recent advances in allergic rhinitis. F1000Res. 2018; 7: F1000 Faculty Rev-1333. Published 2018 Aug 23. doi:10.12688/ f1000research.15367.1

5. Kakli HA, Riley TD. Allergic Rhinitis. Prim Care. 2016 Sep; 43(3): 465-75. doi: 10.1016/j.pop.2016.04.009

6. Stanisławska M. Jakość życia pacjentów z alergicznym niezytem nosa. Fam Med Prim Care Rev. 2015; 17: 3. 
7. Okubo K, Kurono Y, Ichimura K, et al. Japanese guidelines for allergic rhinitis 2020 [published online ahead of print, 2020 May 27]. Allergol Int. 2020; S1323-8930(20)30050-2. doi: 10.1016/j.alit.2020.04.001

8. Emeryk A, Rapiejko P, Lipiec A. Alergiczny nieżyt nosa - kompendium dla lekarzy. Poznań: Wyd. Medyczne Termedia; 2013. p. 25-38.

9. Chazan R. Pneumonologia i alergologia - badania diagnostyczne i postepowanie, $a$ - medica press, 2010/2011, 119-122.

10. Kowalski L. Przedmowa do wydania I. In: Immunoterapia alergenowa; ed. Kowalski M, Rogala B. Łódź: MEDITON; 2012.

11. Rogala B. Komentarz. Postępowanie w alergicznym nieżycie nosa. Podsumowanie wytycznych Allergic Rhinitis and its Impact on Asthma. Med Prakt. 2018; 4: 57.

12. Konradsen J, Arvidsson M. Allergen-specific immunotherapy provides long-lasting symptom relief. Lakartidningen. 2016 Apr 4; 113: DW74

13. Allam JP, Novak N. Immunologische Mechanismen der allergenspezifischen Immuntherapie [Immunological mechanisms of allergenspecific immunotherapy]. Hautarzt. 2017; 68(4): 265-270. doi: 10.1007/ s00105-017-3961-0

14. Głobińska A, Boonpiyathad T, Satitsuksanoa P, et al. Mechanisms of allergen-specific immunotherapy: Diverse mechanisms of immune tolerance to allergens. Ann Allergy Asthma Immunol. 2018; 121(3): 306-312. doi: 10.1016/j.anai.2018.06.026

15. Roberts G, Pfaar O, Akdis CA, et al. EAACI Guidelines on Allergen Immunotherapy: Allergic rhinoconjunctivitis. Allergy. 2018; 73(4): 765-798. doi:10.1111/all.13317

16. Samoliński B, Arcimowicz M, Polskie Standardy Leczenia Nieżytów Nosa. Alergologia Polska 2013.

17. Brożek JL, Bousquet J, Agache I. Medycyna praktyczna dla lekarzy, 13.04.2018 r.

18. Gocki J, Bartuzi Z. Wytyczne/zalecenia. Podskórna i podjęzykowa droga stosowania immunoterapii alergenowej. Schematy leczenia. In: Alergologia Polska. Polish J Allergol. 2018; 5: 137-144.

19. Bartkowiak-Emeryk M. Immunoterapiaalergenowa w alergicznym nieżycie nosa. In: Post Dermatol Alergol. 2012: 32-38

20. Dobrzańska A, Ryżko J, Pediatria, podręcznik do Lekarskiego Egzaminu Końcowego i Państwowego Egzaminu Specjalizacyjnego, ed Dobrzańska A, Ryżko R. Wrocław: ELSEVIER Urban \&Partner; 2014.

21. Cichocka-Jarosz E. Influence of allergen immunotherapy on the quality of life in patients with asthma, allergic rhinitis and insect venom allergy. Alergol Pol - Polish J Allergol. 2018; 5(3): 148-156. doi: 10.5114/ pja.2018.78595

22. Zawadzka-Krajewska A. Alergiczny nieżyt nosa. In: Pediatria, podręcznik do Lekarskiego Egzaminu Końcowego i Państwowego Egzaminu Specjalizacyjnego, ed. Dobrzańska A, Ryżko R. Wrocław: ELSEVIER Urban \&Partner; 2014.

23. Halken S, Larenas-Linnemann D, Roberts G, et al. EAACI guidelines on allergen immunotherapy: Prev Allergy. Pediatr Allergy Immunol. 2017; 28(8): 728-745. doi: 10.1111/pai.12807

24. Nelson HS, Calderon MA, Bernstein DI, et al. Allergen immunotherapy clinical trial outcomes and design: working toward harmonization of methods and principles. Curr Allergy Asthma Rep. 2017 Mar; 17(3): 18. doi: 10.1007/s11882-017-0687-0

25. Petersen KD, Kronborg C, Larsen JN, Dahl R, Gyrd-Hansen D. Patient related outcomes in a real life prospective follow up study: Allergen immunotherapy increase quality of life and reduce sick days. World Allergy Organ J. 2013; 6(1): 15. Published 2013 Sep 9. doi:10.1186/19394551-6-15

26. Roger A, Arcalá Campillo E, Torres MC, et al. Reduced work/academic performance and quality of life in patients with allergic rhinitis and impact of allergen immunotherapy. Allergy Asthma Clin Immunol. 2016; 12: 40. https://doi.org/10.1186/s13223-016-0146-9

27. Filanowicz M, Szynkiewicz E, Cegła B, Bartuzi Z. Analiza jakości życia pacjentów z astmą i alergicznym nieżytem nosa po immunoterapii. Dermatol Alergol. 2016; 33: 134-41.

28. Modrzyński M, Rapiejko P, Zawisza E. Ocena jakości życia chorych z alergicznym nieżytem nosa leczonych za pomocą immunoterapii swoistej. Ann Univ Mariae Curie Sklodowska 2005; 60 (16), 328: 471-475.

29. Lin SY, Erekosima N, Suarez-Cuervo C, et al. Allergen-Specific Immunotherapy for the Treatment of Allergic Rhinoconjunctivitis and/or Asthma: Comparative Effectiveness Review [Internet]. Rockville (MD): Agency for Healthcare Research and Quality (US); 2013 Mar. Report No.: 13-EHC061-EF. PMID: 23638484.

30. Meadows A, Kaambwa B, Novielli N, et al. A systematic review and economic evaluation of subcutaneous and sublingual allergen immunotherapy in adults and children with seasonal allergic rhinitis. Health Technol Assess. 2013 Jul; 17(27): vi, xi-xiv, 1-322. doi: 10.3310/ hta 17270 